\title{
Fundamentals of Gene and Viral Therapy for Malignant Gliomas
}

\author{
Farizan Ahmad ${ }^{1,2}$ and Jafri Malin Abdullah ${ }^{2}$ \\ ${ }^{1}$ Department of Biotechnology and Molecular Medicine \\ A.I. Virtanen Institute for Molecular Sciences, University of Eastern Finland, Kuopio \\ ${ }^{2}$ Department of Neurosciences, School of Medical Sciences \\ Universiti Sains Malaysia, Kelantan \\ ${ }^{1}$ Finland \\ ${ }^{2}$ Malaysia
}

\section{Introduction}

Brain tumors are one of the most devastating cancers in human with approximately 200000 cases reported annually in United States (Khasraw M. \& Lassman A.B, 2010). Among all types of brain tumors, malignant gliomas are the most frequent subtype of primary brain tumors which are categorized into low grade, anaplastic and glioblastoma multiforme depending on the histopathological appearance of the tumors. Malignant brain tumors, including high grade gliomas and brain metastases of carcinomas, are devastating forms of cancer and contribute to a high number of fatalities. According to WHO classification, malignant gliomas include grade III and IV tumors with GBM (WHO grade IV), anaplastic astrocytoma (WHO grade III), malignant oligodendroglioma (WHO grade III) and malignant ependymoma (WHO grade III).

Current treatment options for malignant brain tumors are surgical resection followed with chemotherapy and/or radiotherapy. Despite advances in therapeutic modalities, prognosis of the patients remains poor with a mean survival of 14.6 months after diagnosis and a 5year survival rate of $9.8 \%$ (Wirth T. et al, 2009). Tumor recurrence has been reported to usually occur within 12-months after tumor resection. One of the major obstacles to fight over tumor recurrence is the highly aggressive and invasive nature of tumors which often lead to unsuccessful treatments. Therefore, advancement of therapeutic regimes for treating glioma is crucially needed.

\section{Gene therapy for GBM, the history}

Gene therapy is generally defined as a therapeutic approach for correcting defective genes by delivering genetic materials into cells. Application of viral vector as the main delivery mechanism is consequently called viral gene therapy. Current mostly studied gene therapies involve cancers and hereditary diseases via various approaches. The most important aspect of gene therapy not only to respond specifically in the target area but also to give favorable outcome with the least possible side effects to the patients. 
Glioma is a perfect target for gene therapy for its dismal prognosis, localized growth in the restricted brain areas and absence of metastasis. Advances in gene therapy for brain tumors have started long time ago along with other malignant cancers. In 1992, the first clinical trial for brain tumors was reported by Brenner et al. They studied the delivery mechanism of IL-2 gene using retroviral vectors in neuroblastoma patients. Subsequently in the similar year, Oldfield et al, Ram et al, and Klatzmann et al have initiate another clinical trial using HSV-tk suicide gene therapy approach using Retroviral Vector Producing Cells (VPCs) with intravenous Ganciclovir (GCV). (Oldfield et al, 1993 and Ram et al, 1993)

Currently most utilized gene therapy approaches for brain tumors include suicide gene therapy, cytokine gene therapy, oncolytic virotherapy and immune gene therapy with the main use of retroviruses, herpes simplex virus and adenoviruses. Malignant gliomas are the mostly targeted group for brain tumor gene therapy. The two mainly registered clinical trials for brain tumors are cytotoxic gene therapy and suicide gene therapy methods with a total numbers of 34 and 32 respectively (Määtta et al, 2009). Along with others, a total of 91 gene therapy clinical trials have been reported until September 2009 with 62 in phase I, 17 in phase I/II, 7 in phase II, 1 in phase II/III and 4 in phase III. (www.wiley.co.uk/genetherapy/clinical).

\section{Viral gene therapy/gene delivery vehicles}

Viruses are obligate intra-cellular parasites which generally infecting cells, inserting its DNA into the host genome which is eventually transcribed for the purpose of viral replication. The virus genome contains the basic information of how to produce more copies of their genetic material in order to replicate increase the number of viruses in the host cells. In gene therapy approaches, this virus replication nature has been modified by removing the sequences necessary for the replication and replacing it with the therapeutic gene of interest. The modified virus is subsequently known as viral vector. This modification not only assure the production of the target therapeutic genes but also efficiently working without causing any harm to the host cells (Kanzawa et al, 2003).

Gene delivery vehicles consist of viral and non-viral vectors. Viral vectors which are most commonly used in gene therapy are described in the following table (Table 1). Non-viral vectors used for gene transfer include nucleic acid therapeutics such as antisense oligonucleotide and naked DNA plasmid (Kanzawa et al, 2003).

Delivery mechanism of genetic materials to the patients can be achieved either by direct delivery to the cells (in vivo) or by altering the genes of cells outside of the human body and transfer it back to the patients (ex vivo). Glioblastoma was the first reported cancer to use in vivo technique for gene delivery. (Engelhard H.H., 2005).

\begin{tabular}{|c|c|c|c|}
\hline Vectors & Type & Advantages & Disadvantages \\
\hline $\begin{array}{l}\text { Retrovirus/ } \\
\text { Lentivirus }\end{array}$ & $\begin{array}{l}\text { RNA } \\
\text { virus }\end{array}$ & $\begin{array}{l}\text { - } \quad \text { broad cell tropism } \\
\text { Stable gene expression due to } \\
\text { viral genome integration into } \\
\text { cell chromosomes } \\
\text { - No toxic effect on infected cells, } \\
\text { infect only dividing cells } \\
\text { - Total insert capacity } 8 \mathrm{~kb}\end{array}$ & $\begin{array}{l}\text { Random insertion of viral } \\
\text { genome, possibility of } \\
\text { mutagenesis and oncogene } \\
\text { activation } \\
\text { Possibility of replication } \\
\text { competent virus formation } \\
\text { - } \quad \text { Degraded rapidly by complement } \\
\text { Possible recombination with }\end{array}$ \\
\hline
\end{tabular}




\begin{tabular}{|c|c|c|c|}
\hline & & & human endogenous retroviruses \\
\hline Adenovirus & $\begin{array}{l}\text { DNA } \\
\text { virus }\end{array}$ & $\begin{array}{l}\text { - } \quad \begin{array}{l}\text { very high titers }\left(10^{12} \mathrm{pfu} / \mathrm{ml}\right) \\
\text { expression }\end{array} \\
\text { - } \begin{array}{l}\text { Infect both dividing and non- } \\
\text { dividing cells }\end{array} \\
\text { - } \\
\text { DNA insert capacity } 7-8 \mathrm{~kb}\end{array}$ & $\begin{array}{ll}\text { - } & \text { Inflammatory and toxic host } \\
\text { immune responses } \\
\text { - } & \text { Host's humoral immune } \\
\text { responses may neutralize } \\
\text { adenoviral particles } \\
\text { - } \quad \text { Not suitable for long-term } \\
\text { expression of the transgene } \\
\text { - Complicated vector genome }\end{array}$ \\
\hline Baculovirus & $\begin{array}{l}\text { DNA } \\
\text { virus }\end{array}$ & 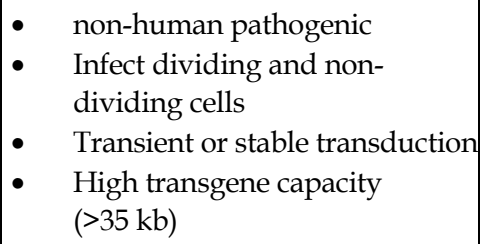 & $\begin{array}{l}\text { - } \quad \begin{array}{l}\text { Inactivated by complement factor } \\
\text { Immunogenicity, elevation of } \\
\text { short term inflammatory reactions }\end{array} \\
\end{array}$ \\
\hline $\begin{array}{l}\text { Adeno- } \\
\text { associated } \\
\text { virus (AAV) }\end{array}$ & $\begin{array}{l}\text { DNA } \\
\text { virus }\end{array}$ & 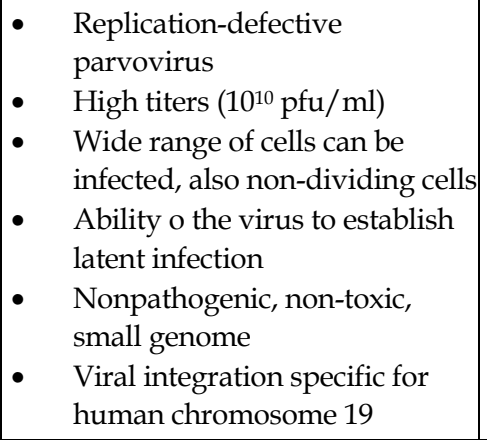 & $\begin{array}{l}\text { - } \begin{array}{l}\text { High titers of pure virus are } \\
\text { difficult to obtain }\end{array} \\
\text { - } \\
\text { AAV requires a helper adeno- or } \\
\text { herpervirus } \\
\text { - } \quad \text { Limited capacity of foreign genes } \\
\text { Lack of specific integration for } \\
\text { recombinant AAV vectors, } \\
\text { possibly mutagenesis } \\
\text { Inefficient due to short-lived in } \\
\text { patients }\end{array}$ \\
\hline $\begin{array}{l}\text { Herpes } \\
\text { simplex virus } \\
\text { (HSV) }\end{array}$ & $\begin{array}{l}\text { DNA } \\
\text { virus }\end{array}$ & \begin{tabular}{|l} 
- \\
DNA virus, titers range from \\
$10^{8}$ to $10^{10} \mathrm{pfu} / \mathrm{ml}$ \\
Does not integrate into the cell \\
genome \\
Long-term expression of the \\
transgene in neuronal cells \\
- $\begin{array}{l}\text { Induce cytopathic effects in } \\
\text { cancer cells }\end{array}$ \\
Transgene capacity $30 \mathrm{~kb}$ \\
without affecting neither titers \\
nor replication \\
Sensitive to antiherpetic agents \\
like ganciclovir, which \\
provides a safety mechanism \\
by which viral replication could \\
be abrogated
\end{tabular} & $\begin{array}{l}\text { - Host immune responses, } \\
\text { inflammatory and toxic reactions } \\
\text { in patients } \\
\text { - } \quad \text { Complicated vector genome } \\
\text { Most people have preexisting } \\
\text { herpes immunity, which could } \\
\text { mpair gene delivery } \\
\text { Ability to infect both replicating } \\
\text { and nonreplicating cells is } \\
\text { undesirable for gene therapy } \\
\text { which requires selective targeting } \\
\text { of replicating cells } \\
\end{array}$ \\
\hline
\end{tabular}

Table 1. Most commonly used viral vectors in gene therapy approaches (Kristiina T. 2006, Immonen A. et al, 2004, Kanzawa et al., 2003 and Romano et al, 2000) 


\section{Viral vectors for gene therapy}

Viral vector is the most important vehicle in gene therapy for its efficiency and specificity to infect host cells and expressing the transgenes. In gene therapy approach for gliomas, retroviruses and adenoviruses have been heavily used in either non-replicating or replicating forms in vivo. Additionally, oncolytic viruses such as HSV-1, Measles, New Castle Disease Virus (NDV), Reovirus, Poliovirus and Vesicular Stomatitis Virus (VSV) have also been tested (Aghi and Chiocca, 2006).

\subsection{Retrovirus (Rv)/lentivirus}

Retrovirus belongs to the family of Retroviridae which is described as RNA type of virus. Rv is highly capable of infecting host cells and reverting its RNA to DNA via reverse transcriptase activity. The formed DNA is subsequently inserted into host genome before being transcribed and translated into protein. (Anson D.S., 2004)

Retroviral vectors are mostly based upon the Moloney murine leukaemia virus (Mo-MLV), an amphotrophic virus which is capable of infecting both mouse cells and human cells thus enabling vector development in mouse models and human treatment.

$\mathrm{Rv}$ genome is relatively small (between 8-11 kb) and easy to manipulate for the use of viral vector production. It can also be produced in high titers $\left(10^{6}-10^{7} \mathrm{pfu} / \mathrm{ml}\right.$ ) (Romano et al, 2000). In viral vector development, genome of $\mathrm{Rv}$ is modified by replacing the genes encoding for $g a g$ (capsid), pol(reverse transcriptase) and env(envelope glycoprotein) with specific transgene of interest (Kristiina T., 2006).

In cases of malignant glioma, $\mathrm{Rv}$ is known to have a vast advantages as a viral vector for its natural activity which is only infecting dividing cells not the non-dividing cells. Therefore, the postmitotic non-dividing brain tissue is left unaffected. $\mathrm{Rv}$ have also shown stable integration of the transgene and leads to long term expression of the target proteins. Additionally, Rv demonstrated safety with minimal risk of toxicity in the use of intracranial application (Aghi \& Chiocca, 2006). However, there are also reported disadvantages including relatively low titers of the Rv packaging cells production, and small size genome limiting transgene insertion into the cassette. Due to the fact that $\mathrm{Rv}$ is integrating into dividing cells, there is high risk of insertional mutagenesis and oncogene activation which may eventually leading to cancer development. (Kanzawa et al, 2003 and Anson D.S., 2004). Lentivirus (Lv) is a subclass of $\mathrm{Rv}$ which is considerably more complex than Rv with additional six proteins, tat, rev, vpr, vpu, nef \& vif. It has been shown that lentivirus can infect both dividing and non-dividing cells in a broad range of tissues, stably integrate into the host genome and produce long term expression in brain, liver, muscles and retina (Miyoshi H. M. et al, 1998).

\subsection{Adenovirus (Ad)}

Adenovirus (Ad) was first isolated from adenoid tissues in 1953 with identification of more than 50 serotypes (Russell, 2009 and Volpers \& Kochanek, 2004). Adenovirus infection often causes illness of respiratory system including acute respiratory infections, pharyngitis and conjunctivitis, epidemic keratoconjunctivitis, gastroentitis and pneumonia in young children.

Ad is characterized by non-enveloped type of virus, icosahedral virus with $60-90 \mathrm{~nm}$ in diameter and having linear double stranded DNA with genome size of 30-40 kb (Volpers \& Kochanek, 2004). Structure of Ad composed of icosahedral capsid consisting of three major 
proteins, hexon (II), penton base (III) and knobbed fibre (IV) with some other minor proteins which give Ad molecular weight of about 150 MDa (Russell, 2009 and Volpers \& Kochanek, 2004). Ad is capable of accommodating up to $10 \mathrm{~kb}$ size of transgene, giving it great advantages in gene therapy purposes (King et al, 2008 and Lam \& Breakefield, 2001).

Ad is the most extensively used viral vector in gene therapy clinical trials. Most frequently used Ad serotypes in gene therapy are Ad2 and Ad5 (Haritha 2008 and Kristiina T. 2006) which are designed as replication defective viruses as generally used in viral vector gene therapy (Engelhard H.H., 2000). Therapeutic genes are designed to be inserted in into regions of E1A and /or E1B genes, and E2 and E4 genes replacing the original virus sequences (Lam \& Breakefield, 2001). However, some drawbacks were reported from this generation of viruses including, 1) maintenance of the viral genome is rapidly lost in dividing cells, 2) viral tumorigenecity, and 3) receptor-mediated uptake of the virus through the primary Ad receptor, CAR, whose expression inversely correlates with malignancy (Aghi and Chiocca, 2006).

Ad is capable of infecting various types of quiescent and proliferating cells including lung, skeletal muscles, heart, liver, blood cells and central nervous system (Haritha 2008). In gene therapy approaches, gene expression from Ad viral vectors occurs without integration of the virus into host genome (Kanzawa et al 2003). Additional advantage of Ad viral vectors are the ability to be produced in high titers (1012-1013 viral particles per $\mathrm{ml}$ ) and low pathogenicity of the virus. However, Ad viral products have been reported to carry high antigenicity and have been associated with toxic and inflammatory responses in brain. Additionally, cytotoxic (CTL)-mediated immune respond often leads to clearance of vector transduced cells and to short duration of transgene expression (Volpers \& Kochanek, 2004 and Lam \& Breakefield, 2001).

\subsection{Other viral vectors}

Herpes Simplex Virus (HSV) is a DNA virus with great advantages for gene therapy application. HSV is a common human pathogen which can be found in most people and infecting both proliferating and non-proliferating cells (Lam \& Breakefield, 2001). Besides the ability to replicate in neuronal cells and kill brain tumor cells, HSV has been shown to cause fatal encephalitis in humans (Biederer et al, 2002).

HSV offers great advantages including ability to be produced in high titers (108 to $10^{10}$ $\mathrm{pfu} / \mathrm{ml}$ ), huge size of transgene (up to $30 \mathrm{~kb}$ in size) can be inserted into HSV genome without affecting the titers or replication, delivery system in CNS is very effective due to neurotropism, sensitive to antiherpetic agents like ganciclovir and HSV has been shown not to integrate into host genome thus reduce the risk of insertional mutagenesis. However, due to its very large viral genome size, the manipulation of the gene becomes more complicated in vitro. Additionally, many people have been detected to have pre-existing HSV in their body thus provides immunity that could lead to gene delivery failure (Aghi \& Chiocca, 2006 and Romano et al, 2000). Two types of HSV that have been used in clinical trial of glioma gene therapy are HSV-G207 and HSV-1716. These two types of viruses are conditionally replicating herpes simplex viruses with specific gene mutations and a selective ability to replicate only within dividing cancer cells, leading to oncolysis (Haritha, 2008).

Another type of virus that has shown promising results in glioma gene therapy is adenoassociated virus (AAV) a type of native human parvovirus. This virus enters the host cells by binding to heparin sulfate and able to replicate via assistance of adenovirus or herpes 
virus. Normally, infection of AAV does not cause any disease in human though integration of the virus genome into host genome occurs. The fact that AAV requires help from either adenovirus or herpes virus for its replication, gives a clear drawback of this virus in gene therapy approach. Additionally, possible transgene that can be inserted into AAV genome is too small (5 kbp only) and gene expression may not be so efficient (Kanzawa et al, 2003).

Other viruses that have been studied in gene therapy for gliomas include Newcastle Disease Virus (NDV), Poliovirus, Measles and Vesicular Stomatitis Virus. NDV is an enveloped negative-stranded oncolytic RNA (Aghi \& Chiocca, 2006) with ability to induce necrosis in cancer. Secretion of different cytokines such as interferon and IL-1 may give anti-tumor effect in gene therapy application (Biederer et al, 2002).

Paliovirus is a RNA virus which can specifically infect and replicate in tumor cells due to tumor-specific expression of human poliovirus receptor CD 155. Paliovirus does not integrate and replicate in postmitotic cells like neurons and has been shown as nonpathogenic in primates. In one study, intracranial injection of the poliovirus resulted in $80 \%$ long-term survival at 50 days in immunodeficient mice (Aghi \& Chiocca, 2006).

\section{Gene therapy strategies for glioblastoma}

Gene therapy undoubtedly holds a great promise for treating various types of cancer including glioblastoma. Currently, we are aware that no single therapeutic will be sufficient to eradicate tumor completely. Therefore, the combination of conventional treatments with novel gene therapy modalities seems to be the preferred choice (Germano IM., 2009). There is a remarkable potential in the rapidly growing gene therapy field for glioblastoma, however to many dismay it has not yet been proven to be a success story in terms of therapeutic options. There are numerous experimental trials on animal models that hold a great promise for malignant glioma treatment (Germano IM., 2009). Nevertheless, in clinical practice there are substantial obstacles to be considered. Currently, only several protocols were adopted in human studies with varying results. As of June 2010 there were 159 cancer gene therapy trials ongoing worldwide, out of which only 13 were targeted against glioma (http://clinicaltrials.gov/). The rate limiting steps for successful gene therapy for brain tumors lie in the efficiency, stability and safety of viral vectors. However, it is believed that the greatest shortcoming comes from the lack of efficiency that is partly caused by the treatment execution and delivery methods.

In this review, gene therapy approaches for gliomas in 4 different categories will be discussed; 1) pro-drug activation/suicide gene therapy; 2) transfer of tumor suppressor genes and cell cycle modulators; 3) genetic immune modulation; and 4) anti-angiogenic gene therapy.

\subsection{Pro-drug activation/suicide gene therapy}

Pro-drug activation which is also known as suicide gene therapy applies the concept of delivering a gene encodes for certain enzyme which can metabolize a non-toxic drug to become toxic (suicide gene) and subsequently kill the tumor cells.

\subsubsection{Herpes simplex virus type 1/tymidine kinase-ganciclovir (HSV-tk/GCV)}

HSV-tk/GCV is the most commonly used gene therapy approaches for glioma. In this twostep therapy approach, HSV-tk enzyme converts non-toxic nucleoside analogs, ganciclovir into phosphorylated compounds which kills actively dividing cells particularly tumor cells (Aghi 
\& Chiocca, 2006 and Wirth et al, 2009). GCV is a synthetic acyclic analogue of 2'-deoxyguanosine, chemically designed as 9-[[2-hydroxy-1-(hydroxymethyl)ethoxy]methyl]guanine. In the pro-drug activation approach, HSV-tk presented a higher capability compared to any other mammalian enzymes to phosphorylating GCV and subsequently changes its conformation into GCV-monophosphate residue (Määtta et al, 2009 and Wirth T. et al, 2009). Further actions by intracellular kinases converts GCV-monophosphate into GCV-triphosphate (GCV-TP) which is capable to inhibit DNA polymerase or its incorporation into DNA, resulting to DNA chain termination. This mechanism of actions specifically targeting DNA replication particularly S-phase-specific, thus giving advantage that only dividing cells or in this case only tumor cells are affected (Fueyo J. et al, 1999, Aghi \& Chiocca, 2006 and Wirth T. et al, 2009).

The efficiency of this approach also depends very much on the bystander effects of the enzyme activities, referring to the killing of cells that are adjacent to the cells transduced with HSV-TK/GCV. These cells do not express the enzyme but receive similar effects through cell-to-cell contact via gap junctions which allow transfer of Ganciclovir triphosphate from HSV-TK+ cells to non-transduced cells. Activation of the enzyme in the transduced and adjacent cells allow formation of the cytotoxic molecules which contribute to the increment of the treatment efficiency and cells death (Aghi and Chiocca, 2006, Kanzawa et al., 2003).

Gene therapy via HSV-tk approach has undergone clinical trial (phase III) in many countries using retrovirus and most recently adenovirus (Kanzawa at al, 2003 and Asadi-Moghaddam K. and Chiocca E.A, 2009). Until September 2008, a total of 34 clinical trials were registered worldwide with malignant glioma being the biggest sub-group treated. HSV-tk has been the most widely used approach with 32 clinical trials (Maatta et al, 2010).

\subsubsection{CD/5-FC combination}

5-Fluoro Cytosine (5-FC) is an anti-fungal agent that is generally used to treat fungal infection (Asadi-Moghaddam K. and Chiocca E.A, 2009). In gene therapy modality, this prodrug is converted into active and toxic form of 5-fluorouracil (5-FU) by enzyme called cytosine deaminase (CD). The toxic effects of 5-FU is mediated by its intracellular metabolites, via conversion of 5-FU onto 5-fluoro-2'-deoxyuridine-5'-monophosphate, causes DNA strand breakage leading to cell death (Aghi and Chiocca, 2006).

It has been shown that tumor cells receiving CD may present CD peptides on the MHC Class I which could lead to immune response activation. $\mathrm{CD} / 5-\mathrm{FU}$ combination renders a strong bystander effects compared to HSV-tk due to its ability to diffuse via membrane cells and enters the nontransduced cells (Lam \& Breakefield, 2003). Adenovirus has been used in the experimental studies for CD/5-FU combination. There is one registered study which is now in the stage of recruiting patients for the Phase I clinical trials (http:/ / clinicaltrials.gov).

\subsubsection{Cytochrome P450 2B1/cyclophosphamide (CPA)}

Another pro-drug activating enzyme that has been well-characterized in gene therapy is rat cytochrome P450 2B1/cyclophosphamide (CPA). CPA is a pro-drug agent that can be activated by liver-specific enzyme of the cytochrome P450 family via its conversion to phosphoramide mustard (PM). PM relatively appears in a stable and diffusible form with ability to enter adjacent cells without contact-dependent bystander effects. (Aghi and Chiocca, 2006) 
This approach has initially been developed for the use in brain tumor (Chen L. et al, 1997). Studies using retrovirus have shown great promise to reduce glioma formation in mice (Manome et al, 1996 and Wei et al, 1995). Additionally, manipulation of replicationconditional HSV vector has been used for carrying P450 2B1/CPA in glioma treatment (Aghi et al, 1999). Manipulated HSV-1 virus carrying P450 gene acts via 3 modes; 1 ) using viral oncolysis; 2 ) rendering the infected cells to CPA; 3 ) rendering the infected cells to GCV (Asadi-Moghaddam K. and Chiocca E.A, 2009).

Besides the ability to diffuse via membrane to the neighboring cells, use of cytochrome P450 also less immunogenic than other suicide gene therapy such as HSV-tk thus provides long term drug activation (Karle P. et al, 2001). However, due to the fact that cyclophosphamide's active metabolites can only be generated by liver P450 and these metabolites are poorly transported across BBB, there may be some limitation of the use in treating glioma (Aghi and Chiocca, 2006).

\subsection{Transfer of $\mathrm{p} 53$ tumor suppressor genes}

Various studies have shown that alterations of different oncogenes and tumor suppressor genes that control the cycle cycle involved in glioma progression. The alteration may cause disruption of normal functions of the genes and lead to the uncontrolled proliferation of cancer cells (Garrett, 2001). The reported mechanisms by which could abolish the normal functions of the tumor suppressor genes include loss of heterozygosity, methylation, cytogenetic aberrations, genetic mutations, gain of autoinhibitory function and polymorphism (Zingde, 2001).

One of the most widely studied is p53 tumor suppressor gene which is generally inactivated in $35-60 \%$ if human malignant gliomas (Kanzawa et al, 2003). Pre-clinical trials with adenovirus mediated p53 gene transfer demonstrated promising results with growth inhibition of transplated glioma and prolongation of the survival in the models. Lang et al in his phase I clinical trial also reported median survival of the glioma patients was 10 months and no-recurrence has been reported in 1 patient for up to 3 years. Lang et al in their studies used two-staged approach for delivering the therapeutic genes; adenovirus vector containing p53 gene was injected intratumorally via a stereotactically implanted catheter, whereafter the tumor and catheter were resected en bloc and re-injections (up to $3 \times 10^{12} \mathrm{vp}$ ) were performed into the walls of the tumor cavity. (Pulkkanen \& Ylä-Herttuala, 2005 and Lang et al, 2003)

There are also reports that p53 gene transfer is not effective to wild type p53 and glioma is a mixture of cells with mutated p53 and wild-type p53 resulted to partially effective p53 gene therapy. In relation to that, p53 gene therapy combinations have been introduced in order to increase the therapeutic effects. For example, p53 in combination with radiation improves the positive effects in heterogenous cells (Fueyo J. et al, 1999). Interesting study by Huang et al showed that combination therapy of p53 with HSV-tk/GCV suicide gene therapy demonstrated a synergistic effect in C6 rat glioma model (Huang et al, 2007). P53 in combination with oncolytic virotherapy has improved the survival in animal models (Geoerger et al., 2004).

Other therapeutic genes that hold great promise to glioma gene therapy include epidermal growth factor receptor gene, which is often amplified in malignant gliomas (AsadiMoghaddam K. and Chiocca E.A, 2009). 


\subsection{Immuno gene therapy}

The concept of immune gene modulation in cancers implies the use of various cytokines to enhance the immune response against tumor cells. Most widely studied cytokines in malignant gliomas are interleukin IL-2, IL-4, IL-12, interferon (IF)- $\beta$, IF- $\gamma, 39$ and granulocyte-macrophage colony stimulating factor (GM-CSF) (Kanzawa et al, 2003 and Lam \& Breakefield, 2001).

Malignant glioma is a great target for immune gene therapy because of its structure that consists of blood brain barrier (BBB) and without any drainage system. Immuno gene therapy can be achieved either via active or passive strategies. Active immunotherapy provides long-term effect immunity via up regulating the immune response. On the other hand, passive immunotherapy applies the delivery of immune effectors to achieve immediate effect but for short term immunity. Various studies are currently ongoing for both active and passive immune gene therapy for glioma (Clarke J. et al, 2010).

Inductions of cytokines production in gliomas are achieved either by direct cells transplant or genetically engineered virus which carries specific transgenes. One of the promising immune gene therapy approaches is using EGFRvIII as tumor specific antigen to induce immune system to fight against the tumor cells. This study has entered phase $2 / 3$ clinical trial with promising results (Yamanaka, 2008).

Other cytokine that have shown efficacy in experimental animals is IFN- $a$. IFN- a inhibits cell cycle progression and induces apoptosis in tumor cells thereby leading to enhanced immune system reaction by increasing expression of MHC-1 (King 2005 and Yang 2004). IFN- a has shown to regress glioma in animal model when co-delivered with DCs into the tumor (Tsugawa 2004).

\subsection{Anti-angiogenic gene therapy}

One of the promising areas to improve the efficiency of the gene therapy is by targeting angiogenesis in the gliomas. Increasing evidences have shown that similar to any other solid tumors, malignant gliomas require sufficient blood supply to sustain growth and glioblastomas have been shown to be the most densely vascularized human tumor (Kunkel et al., 2001). Since 1971, the idea of inhibition of angiogenesis has emerged and lead to extensive research towards identifying and isolating the regulators of angiogenesis, some of which represent therapeutic targets.

Angiostatin, an internal peptide fragment of plasminogen, has recently been shown to potently inhibit endothelial proliferation in vitro and tumor growth in vivo. Animal experiments carried out by Griscelli and co-workers (1998) showed decreased tumor volume, decreased tumor vascularity and increased tumor cell apoptosis in nude mouse model injected with adenovirus expressing angiostatin. Recombinant angiostatin has also been reported to inhibit growth and neovascularization of intracerebral glioma xenografts, as well as to increase tumor cell apoptosis (Rege et al., 2005).

Endostatin, a 20-kDa carboxyl-terminal proteolytic cleavage fragment of collagen 18 is also a potential angiogenic inhibitor. Endostatin was originally reported to inhibit the proliferation of bovine capillary endothelial cells, but not the proliferation of cells of nonendothelial origin, and also inhibit angiogenesis in the chick chorioallantoic membrane model. However, complete tumor inhibition was not observed in either the athymic or immunocompetent animal glioma models (Rege et al., 2005, Kanzawa et al., 2003).

Despite some failures and ongoing research in finding anti-angiogenic therapies for gliomas, some of the researchers are interested with the potential of bevacizumab (avastin) shown in non-small-cell-lung cancer, renal cell cancer and metastatic breast cancer. Bevacizumab is 
anti-VEGF-A which has been approved by the US Food and Drug Administration (FDA) for the treatment of metastatic colorectal cancer in combination with 5-fluorouracil (FU)-based chemotherapy regimens. Clinical trials of bevacizumab for malignant glioma patients have been carried out by some researchers but conclusive data is not yet been published. (Vredenburgh J.J., 2007, Rose S.D and Aghi M.K, 2010)

\section{Conclusion}

Advances in the approach of gene therapy for gliomas via pro-drug activation/suicide gene therapy, transfer of tumor suppressor genes and cell cycle modulators, genetic immune modulation and anti-angiogenic gene therapy have shown great promises to better the current treatment regimes. Either being delivered in single or combination with other conventional treatment, gene therapy is anticipated to be able to translate the successful findings from animal experiments to clinical application. In clinical practice, the challenges are not only to fight the extreme invasive and aggressive nature enclosed in malignant gliomas, but also to overcome the difficulties of delivering modified virus vectors into the solid tumor as well as to ensure the efficiency of the genetic transfer. Currently, gene therapy for gliomas is studied in different clinical trials phases.

\section{References}

Aghi M., Chou T.C., Suling K., Breakefield X.O., Chiocca E.A. (1999). Cancer Res. Multimodal cancer treatment by a replicating oncolytic virus that delivers the oxazophosphorine/rat cytochrome P4502B1 and ganciclovir/herpes simplex virus thymidine kinase gene therapies. 59, pp. 3861-3865

Anson D. S. (2004) Genetic Vaccines and Therapy. The use of retroviral vectors for gene therapywhat are the risks? A review of retroviral pathogenesis and its relevance to retroviral vectormediated gene delivery. 2, 9

Biederer C., Ries S., Brandts C.H. and Frank McCormick. (2002) J Mol Med. Replicationselective viruses for cancer therapy. 80, pp. 163-175

Chen L., Yu L. J. and Waxm D.J. (1997) Cancer Res. Potentiation of Cytochrome P450/Cyclophosphamide-based Cancer Gene Therapy by Coexpression of the P450 Reductase Gene. 57, pp 4830-4837

Clarke J, Butowski N., Chang S. (2010) Arch Neurol. Recent Advances in Therapy for Glioblastoma. 67, 3, pp 279-283

Engelhard H.H. (2000). Surg Neurol. Gene Therapy for Brain Tumors: the Fundamentals. 54, pp 3-9

Fueyo J., Gomez-Manzano C., Alfred Yung W. K., Kyritsis A.P. (1999) Arch Neurol. Targeting in Gene Therapy for Gliomas. 46, pp 445-448

Garrett, M. D. (2001). Current Science. Cell cycle control and cancer. 81, pp. 515-522

Germano IM, Binello E. (2009). J. Neurooncol. Gene therapy as an adjuvant treatment for malignant gliomas: from bench to bedside. 93, 1, pp. 79-87

Geoerger B., Vassal G., Opolon P., Dirven C.M., Morizet J., Laudani L., Grill J., Giaccone G., Vandertop W.P., Gerritsen W.R., van Bausechem V.W., (2004) Cancer Res. Oncolytic activity of p53-expressing conditionally replicating adenovirus AdDelta24-p53 against human malignant glioma. 64, pp. 5753-5759

Haritha D. Samaranayake (2008) Combination Gene Therapy for Malignant Glioma. Thesis for Masters Degree in Biotechnology and Molecular Medicine, Biotechnology and Molecular Medicine Department, A.I.Virtanen Institute, University of Kuopio, Finland 
Huang Q., Pu P., Xia Z., You Y., (2007) J. Neurooncol. Exogenous wt-p53 enhances the antitumor effect of HSV-TK/GCV on C6 glioma cells. 82, pp. 239-248

Im S, Gomez-Manzano C, Fueyo J, et al. (1999) Cancer Res. Antiangiogenesis treatment for gliomas: transfer ofantisense-vascular endothelial growth factor inhibits tumor growth in vivo. 59, pp 895-900

Immonen A., Vapalahti, M., Tyynela, K., Hurskainen, H., Sandmair, A., Vanninen, R., Langford, G., Murray, N. \& Yla-Herttuala, S. (2004) Mol Ther. AdvHSV-tk gene therapy with intravenous ganciclovir improves survival in human malignant glioma: a randomised, controlled study. 10, 5, pp 967-971

Kanzawa, T., Ito, H., Kondo, Y. \& Kondo, S. (2003) Journal of Biomedicine and Biotechnology. Current and Future Gene Therapy for Malignant Gliomas. 1, pp 125-34

Karle P, Renner M, Salmons B. and Gunzburg W.H. Cancer (2001) Gene Therapy. Necrotic, rather than apoptotic, cell death caused by cytochrome P450-activated ifosfamide. 8, 3, pp 220-230

Kaveh Asadi-Moghaddam and E. Antonio Chiocca. (2009) Neurotherapeutics. Gene- and Viral-Based Therapies for Brain Tumors. 6, 3, pp 547-557

Khasraw M and Lassman A.B. (2010) Current Oncology Rep. Advances in the Treatment of Malignant Gliomas. 12, pp 26-33

King G.D., Curtin J.F., Candolfi M., Kroeger K., Lowenstein P.R., Castro M.G., (2005) Curr. Gene Ther. Gene therapy and targeted toxins for glioma. 5, pp. 535-557

King G.D., Ghulam Muhammad A.K.M, Xiong W., Kroeger K.M., Puntel M., Larocque D., Palmer D., Ng P., Pedro R. Lowenstein, and Maria G. Castro (2008) Journal of Virology. High-Capacity Adenovirus Vector-Mediated Anti-Glioma Gene Therapy in the Presence of Systemic Antiadenovirus Immunity. 82, 9, pp. 4680-4684

Kristiina Tyynela (2006) Gene Therapy of Malignant Glioma. Experimental and Clinical Studies. Doctoral Dissertation. Biotechnology and Molecular Medicine, Biotechnology and Molecular Medicine Department, A.I.Virtanen Institute, University of Kuopio, Finland

Kunkel, P., Ulbricht, U., Bohlen, P., Brockmann, M. A., Fillbrandt, R., Stavrou, D., Westphal, M. \& Lamszus, K. (2001) Cancer Research. Inhibition of glioma angiogenesis and growth in vivo by systemic treatment with a monoclonal antibody against Vascular Endothelial Growth Factor Receptor-2. 61, pp 6624-6628

Lam, P. Y. P. \& Breakefield, X. O. (2001) Human Molecular Genetics. Potential of gene therapy for brain tumors. 10, pp 777-787

Lang F. F., Bruner J.M, Fuller G.N, Aldape K., Prados M.D., Chang S., Berger M.S., McDermott M.W., Kunwar S.M., Junck L.R., Chandler W., Zwiebel J.A., Kaplan R.S., Alfred Yung W.K. (2003). J. Clin. Oncol. Phase I trial of adenovirus-mediated p53 gene therapy for recurrent glioma: biological and clinical results. 21, pp. $2508-2518$

Määtta A., Samaranyake H., Pikkarainen J., Wirth T. and Ylä-Herttuala S. (2009) Current Gene Therapy. Adenovirus Mediated Herpes Simplex Virus-Thymidine Kinase/Ganciclovir Gene Therapy for Resectable Malignant Glioma. 9, 5, pp. 356-367

Manome Y, Wen P, Chen L, et al. (1996) Gene Ther. Gene therapy for malignant gliomas using replication incompetent retroviral and adenoviral vectors encoding the cytochrome P450 2B1 gene together with cyclophosphamide. 3, pp 513-520

Miller C, Williams C, Buchsbaum D, Gillespie G. (2002) Cancer Res. Intratumoral 5fluorouracil produced by cytosine deaminase/5-fluorocytosine gene therapy is effective for experimental human glioblastomas. 62, pp 773-780

Miyoshi H., Blomer U., Takahashi M., Gage F.H. and Verma I.M. (1998) Journal of Virology. Development of a Self-Inactivating Lentivirus Vector. 72, 10, pp 8150-5157 
Oldfield EH, Ram Z, Culver KW, Blaese RM, DeVroom HL, Anderson WF (1993) Human Gene Ther. Gene Therapy for the treatment of brain tumors using intra-tumoral transduction with the thymidine kinase gene and intravenoud ganciclovir. 4, 1, pp 39-69

Pulkkanen K.J and Yla-Herttuala S. (2005) Molecular Therapy. Gene Therapy for Malignant Glioma:Current Clinical Status. 12, 4, pp 585-598

Ram Z, Culver KW, Walbridge S, Blaese RM, Oldfield EH. (1993) Cancer Res. In situ retroviral-mediated gene transfer for the treatment of brain tumors in rats. 53, 1, pp 83-88

Rege, T. A., Fears, C. Y. \& Gladson, C. L. (2005) Neuro-oncology. Endogenous inhibitors of angiogenesis in malignant gliomas: Nature's antiangiogenic therapy. 7, 2, pp 106-121

Romano G., Micheli P., Pacilio C., Giordano A. (2000). Stem Cells Latest Developments in Gene Transfer Technology: Achievements, Perspectives, and Controversies over Therapeutic Applications. 18, pp.19-39

Russell W. C. (2009) Journal of General Virology. Adenoviruses: update on structure and function. 90, pp 1-20

Samuel D. Rose and Manish K. Aghi. (2010) Clinical Neurosurgery. Mechanisms of Evasion to Antiangiogenic Therapy in Glioblastoma. 57, pp 123-128

Sandmair, A. M., Turunen, M., Tyynela, K., Loimas, S., Vainio, P., Vanninen, R., Vapalahti, M., Bjerkvig, R., Jane, J. \& S. Yla-Herttuala. (2000) Cancer Gene Therapy. Herpes simplex virus thymidine kinase gene therapy in experimental rat BT4C glioma model: effect of the percentage of thymidine kinase-positive glioma cells on treatment effect, survival time and tissue reactions. $7, \mathrm{pp}$ 413-421

Tjuvajev J, Gansbacher B, Desai R, et al. (1995) Cancer Res. RG-2 glioma growth attenuation and severe brain edema caused by local production of interleukin-2 and interferon-gamma. 55, pp 1902-1910

Tsugawa T., Kuwashima N., Sato H., Fellows-Mayle W.K., Dusak J.E., Okada K., Papworth G.D., Watkins S.C., Gambotto A., Yoshida J.,Pollack I.F., Okada H., (2004) Gene Ther. Sequential delivery of interferon-alpha gene and DCs intracranial gliomas promotes an effective antitumor response. 11, pp.1551-1558

Volpers C. and Kochanek S. (2004) J Gene Med. Adenoviral vectors for gene transfer and therapy. 6, pp. S164-S171

Vredenburgh J.J, Desjardins A., Herndon II J.E., Dowell J.M., Reardon D.A, Quinn J.A, Rich J.N, Sathornsumetee S., Gururangan S., Wagner M., Bigner D.D, Friedman A.H., and Friedman H.S. (2007) Clin Cancer Res. Phase II Trial of Bevacizumab and Irinotecan in Recurrent Malignant Glioma. 13, 4, pp 1253-1259

Vredenburgh J.J, Desjardins A., Herndon II J.E., Dowell J.M., Reardon D.A, Quinn J.A, Rich J.N, Sathornsumetee S., Gururangan S., Wagner M., Bigner D.D, Friedman A.H., and Friedman H.S. (2007) J Clin Oncol. Bevacizumab plus irinotecan in recurrent glioblastoma multiforme. 25, 30, pp 4722-4729

Wei M, Tamiya T, Rhee R, Breakefield X, Chiocca E. (1995) Clin. Cancer Res. Diffusible cytotoxic metabolites contribute to the in vitro bystander effect associated with the cyclophosphamide/cytochrome P450 2B1 cancer gene therapy paradigm. 1, pp 1171-1177

Wirth T., Samaranyake H., Pikkarainen J., Maatta A. \& Ylä-Herttuala S. (2009) Current Opinion in Molecular. Therapeutics Clinical trials for glioblastoma multiforme using adenoviral vectors. 11, 5, pp 485-492

Yamanaka R. (2008) Trends Mol Med. Cell- and peptide-based immunotherapeutic approaches for glioma. 14, 5, pp 228-235.

Zingde, S. M. (2001) Current Science. Cancer genes. 81, 5, pp 508-514

Yang S.Y., Liu H., Zhang J.N., (2004) DNA Cell Biol. Gene therapy of rat malignant gliomas using neural stem cells expressing IL-12. 23, pp. 381-389 


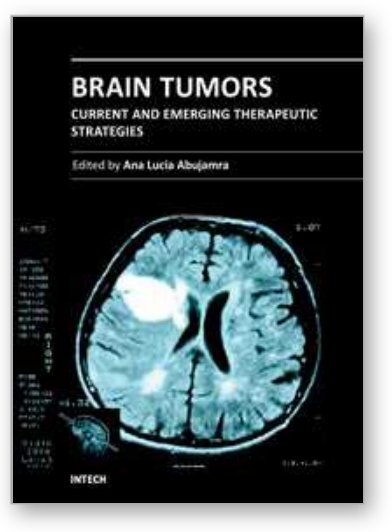

\author{
Brain Tumors - Current and Emerging Therapeutic Strategies \\ Edited by Dr. Ana Lucia Abujamra
}

ISBN 978-953-307-588-4

Hard cover, 422 pages

Publisher InTech

Published online 23, August, 2011

Published in print edition August, 2011

Brain Tumors: Current and Emerging Therapeutic Strategies focuses on tumor models, the molecular mechanisms involved in the pathogenesis of this disease, and on the new diagnostic and treatment strategies utilized to stage and treat this malignancy. A special section on immunotherapy and gene therapy provides the most up-to-date information on the pre-clinical and clinical advances of this therapeutic venue. Each chapter in Brain Tumors: Current and Emerging Therapeutic Strategies is authored by international experts with extensive experience in the areas covered.

\title{
How to reference
}

In order to correctly reference this scholarly work, feel free to copy and paste the following:

Farizan Ahmad and Jafri Malin Abdullah (2011). Fundamentals of Gene and Viral Therapy for Malignant Gliomas, Brain Tumors - Current and Emerging Therapeutic Strategies, Dr. Ana Lucia Abujamra (Ed.), ISBN: 978-953-307-588-4, InTech, Available from: http://www.intechopen.com/books/brain-tumors-current-andemerging-therapeutic-strategies/fundamentals-of-gene-and-viral-therapy-for-malignant-gliomas

\section{INTECH}

open science | open minds

\section{InTech Europe}

University Campus STeP Ri

Slavka Krautzeka 83/A

51000 Rijeka, Croatia

Phone: +385 (51) 770447

Fax: +385 (51) 686166

www.intechopen.com

\section{InTech China}

Unit 405, Office Block, Hotel Equatorial Shanghai

No.65, Yan An Road (West), Shanghai, 200040, China

中国上海市延安西路65号上海国际贵都大饭店办公楼 405 单元

Phone: +86-21-62489820

Fax: +86-21-62489821 
(C) 2011 The Author(s). Licensee IntechOpen. This chapter is distributed under the terms of the Creative Commons Attribution-NonCommercialShareAlike-3.0 License, which permits use, distribution and reproduction for non-commercial purposes, provided the original is properly cited and derivative works building on this content are distributed under the same license. 